Historic, archived document

Do not assume content reflects current scientific knowledge, policies, or practices. 



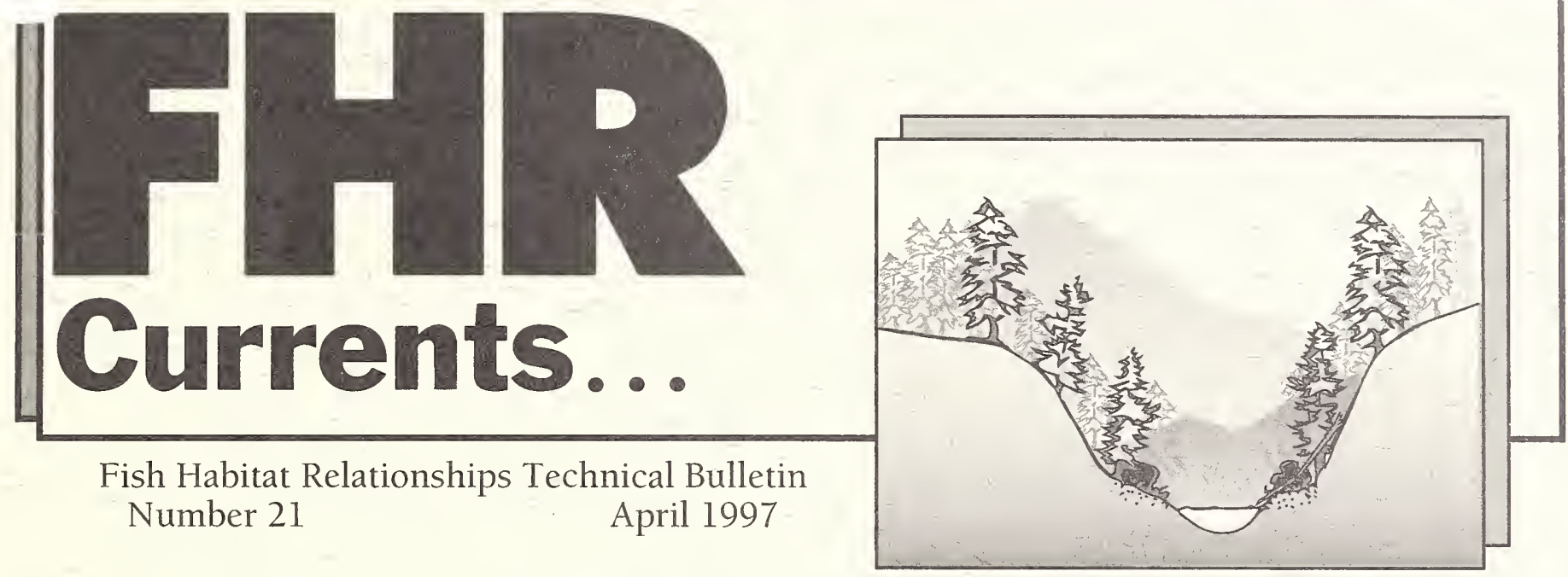

\title{
Evaluating the Long-Term Consequences of Forest Management and Stream Cleaning on Coarse Woody Debris in Small Riparian Systems of the Central Rocky Mountains
}

\author{
Don C. Bragg and Jeffrey L. Kershner ${ }^{2}$ \\ ${ }^{1}$ Department of Forest Resources and Ecology Center, \\ Utah State University, Logan UT 84322-5212 \\ ${ }^{2}$ National Fish Habitat Relationships Program, USDA Forest Service, \\ Department of Fisheries and Wildlife, \\ Utah State University, Logan UT 84322-5210
}

\begin{abstract}
Coarse woody debris (CWD), while often providing the primary source of structure in small streams, has been frequently subjected to intensive removal efforts with uncertain long-term consequences. We present the integration of a growth and yield model (FVS) with a mechanistic recruitment model (CWD) to simulate long-term effects of both harvesting and CWD removal from streams in northwestern Wyoming. The CWD model predicted a gradual recovery from stream cleaning 80 - 110 years later, but both selective harvesting and clearcutting significantly decreased the volume of material entering the stream when compared to uncut controls. The combination of stream cleaning and clearcutting frequently limited the total CWD load to $<10 \%$ of undisturbed levels. Selective harvesting of riparian forests, while decreasing CWD inputs, may deliver enough to allow harvests in some systems when coupled with proactive CWD management. Proactive management, in this sense, means we may want to deliberately form snags or initiate CWD delivery, or at least retain favorable trees in the residual stand to ensure continued CWD recruitment.
\end{abstract}




\section{FHR Currents Purpose}

The USDA Forest Service Fish Habitat Relationships Program was established to further the development of fisheries technology and transfer this technology to field biologists. With ever increasing demands for natural resources, protection and management of aquatic communities requires biologists to be knowledgable of current research findings and state-ofthe-art techniques. The purpose of FHR Currents is to provide a vehicle to quickly disseminate information important to fieldlevel biologists in the USDA Forest Service.

\section{Submissions:}

If you wish to submit a paper for publication in FHR Currents, please contact the following people for information and guidelines.

Jerry Boberg/Karen Kenfield

Technical Editors

(707)441-3669

Six Rivers National Forest

Fisheries Department

1330 Bayshore Way

Eureka, CA 95501

\section{Forest Service Fish Habitat Relationships Program Leaders or Representatives}

\section{National FHR Program}

Jeffrey L. Kershner, Washington Office Fish \& Wildlife Department

Utah State University

Logan, UT 84322-5210

\section{Region 1}

Kathy Moynan, Northern Region

(Anadromous Fish Program)

Nez Pierce National Forest

Route 2, Box 475

Grangeville, ID 83530

Brian Sanborn, Northern Region

(Resident Fish Program)

Deerlodge National Forest

Federal Building, Box 400

Butte, MT 59703

\section{Region 2}

R. Nick Schmal, Rocky Mountain Region Wildlife, Fish \& Botany Staff

Univ. of Wyoming, College of Agriculture Laramie, WY 82071-3354

\section{Region 3}

Bryce Rickel, Southwest Region

Wildlife, Fish \& Botany Staff

Federal Building

517 Gold Avel, S.W.

Albuquerque, NM 87102

\section{Region 4}

Seona L. Brown, Intermountain Region Wildlife, Fish \& Botany Staff

32425 th St.

Ogden, UT 84401

\section{Region 5}

Jerry Boberg, Pacific Southwest Region (Anadromous Fish Program)

Six Rivers National Forest

1330 Bayshore Way

Eureka, CA 95501

Jeffery Reiner, Pacific Southwest Region (Resident Fish Program)

Lake Tahoe Basin Management Unit

870 Emerald Bay Rd., Suite 1

South Lake Tahoe, CA 96150

\section{Region 6}

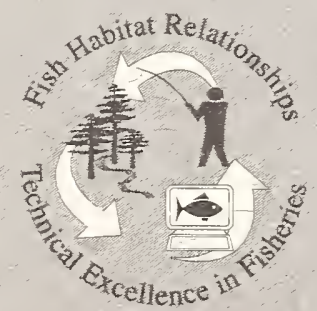

333 S.W. 1st Ave., P.O. Box 3623

Portland, OR 97208

\section{Region 8}

Cindy A. Williams, Southern Region Wildlife, Fish \& Botany Staff

1720 Peachtree Rd.

N.W. Atlanta, GA 30367

\section{Region 9}

Bob Hollingsworth, Northeast Region USDA Forest Service 310 W. Wisconsin Ave.

Milwaukee, WI 53203

\section{Region 10}

Ron Dunlap, Alaska Region Wildlife, Fish \& Botany Staff Federal Office Building, Box 21628 Juneau, AK 99802-1628

\section{Intermountain/Northern Region}

Kerry Overton, Fish Research Work Unit Intermountain Research Station 316 E. Myrtle St.

Boise, ID 83702

\section{Associates}

\section{Glenn Chen}

Fisheries Biologist/Monitoring Specialist USDA Forest Service

Fish \& Wildlife Department

Utah State University

Logan, UT 84322-5210

Fred Mangum

Aquatic Ecosystem Analysis Lab

105 Page School

Brigham Young University

Provo, UT 84602

Ken Roby

Hydrologist, USDA Forest Service

Pacific Southwest Experiment Station

P.O. Box 245

Berkeley, CA 94701-0245

Larry Schmidt

Stream Systems Technology Center USDA Forest Service

Rocky Mountain Experiment Station 240 W. Prospect

Fort Collins, CO 80526-2098

Mark Vinson

Hydrologist/Monitoring Specialist

USDI Bureau of Land Management

Fish \& Wildlife Department

Utah State University

Logan, UT 84322-5210 


\section{Introduction}

For decades we have cultured a rather antagonistic relationship with instream coarse woody debris [CWD- pieces of wood at least 10 $\mathrm{cm}$ in diameter and $1 \mathrm{~m}$ long (McDade et al. 1990, Richmond and Fausch 1995)]. For the sake of navigation, mining, or fish migration, humans have extracted great quantities of CWD from rivers and streams, often with unanticipated and detrimental consequences (Swanson and Lienkaemper 1978, Beschta 1979, Bilby 1984, Harmon et al. 1986, House and Boehne 1987, Young et al. 1994). Recent research has shed a considerably more positive light on the influence of CWD on creating fish habitat, organic carbon production, and CWD effects on channel morphology (e.g., Swanson et al. 1982, Megahan 1982, Harmon et al. 1986, Bisson et al. 1987).

Riparian forests are critical sources of CWD. Murphy and Koski (1989) and McDade et al. (1990) estimated that $>70 \%$ of riparian CWD was generated within $20 \mathrm{~m}$ of the bank. The preservation of an intact, continuous buffer of riparian forests has frequently been cited as necessary for sustaining CWD delivery to a stream (e.g., Murphy and Koski 1989, McDade et al. 1990, Potts and Anderson 1990). Resource managers in many areas are faced with the dilemma of integrating forest management practices with sensitive riparian zones, and frequently lack the tools to prescribe management plans that consider both timber and riparian needs. To address some of these concerns, we have developed an analysis tool driven by a growth and yield model [the Forest Vegetation Simulator (FVS)] that predicts CWD delivery to the stream through a combination of stochastic and deterministic processes. Originally calibrated for small Engelmann spruce (Picea engelmannii) and subalpine fir (Abies lasiocarpa) dominated streams on the Bridger-Teton National Forest in northwestern Wyoming, the objective of the CWD model is to help biologists and silviculturists predict CWD delivery in riparian zones under a variety of management options.

In designing this model, we had twofold intentions. First, we wanted to hypothetically simulate how management actions influence CWD recruitment and delivery to streams, even though it is not current federal policy to harvest riparian forests in this manner. This exercise provided insights as to what information is most important when melding a growth and yield model with this kind of post-processor. These simulations were more than simply academic, however, as it is also conceivable that private or industrial landowners, less constrained by buffer regulation, may be interested in some level of harvesting in riparian forests. Eventually, some agencies may also decide to adopt other buffer policies to address habitat variegation concerns, which could include limited entries for harvesting.

Regardless of current riparian forest management, CWD's greatest applicability may come from the information it can provide on the restoration of damaged streams. Until recently, stream clearing and riparian forest cutting were standard practices across much of the western United States (see Froehlich 1973, Bilby 1984, Bisson et al. 1987, Young et al. 1994). These practices have resulted in many streams depauperate of CWD, and if simultaneously heavily cut, there may be little forest remaining from which to recruit new pieces. CWD can be used, in conjunction with historical inventories, to forecast recovery periods (given forest type and growth rates) and indicate if natural CWD recovery shall be sufficient or if further human intervention is needed.

\section{Methods}

\section{Study Area Descriptions}

Field sites were sampled in the Bridger-Teton National Forest (Appendix A) during the summer of 1995 to provide both model parameterization and riparian stands for future simulation (Figure 1). Small (first- to third-order) streams were selected because of the importance of CWD in these systems (Swanson et al. 1976), and because they are the most likely stream systems in this region to possess adjacent, continuous spruce-fir forests. Sampled streams tended to be low to moderate in gradient $(<10 \%)$ and low in sinuosity (Appendix A). Table 1 lists the physical parameters of the three streams selected for 


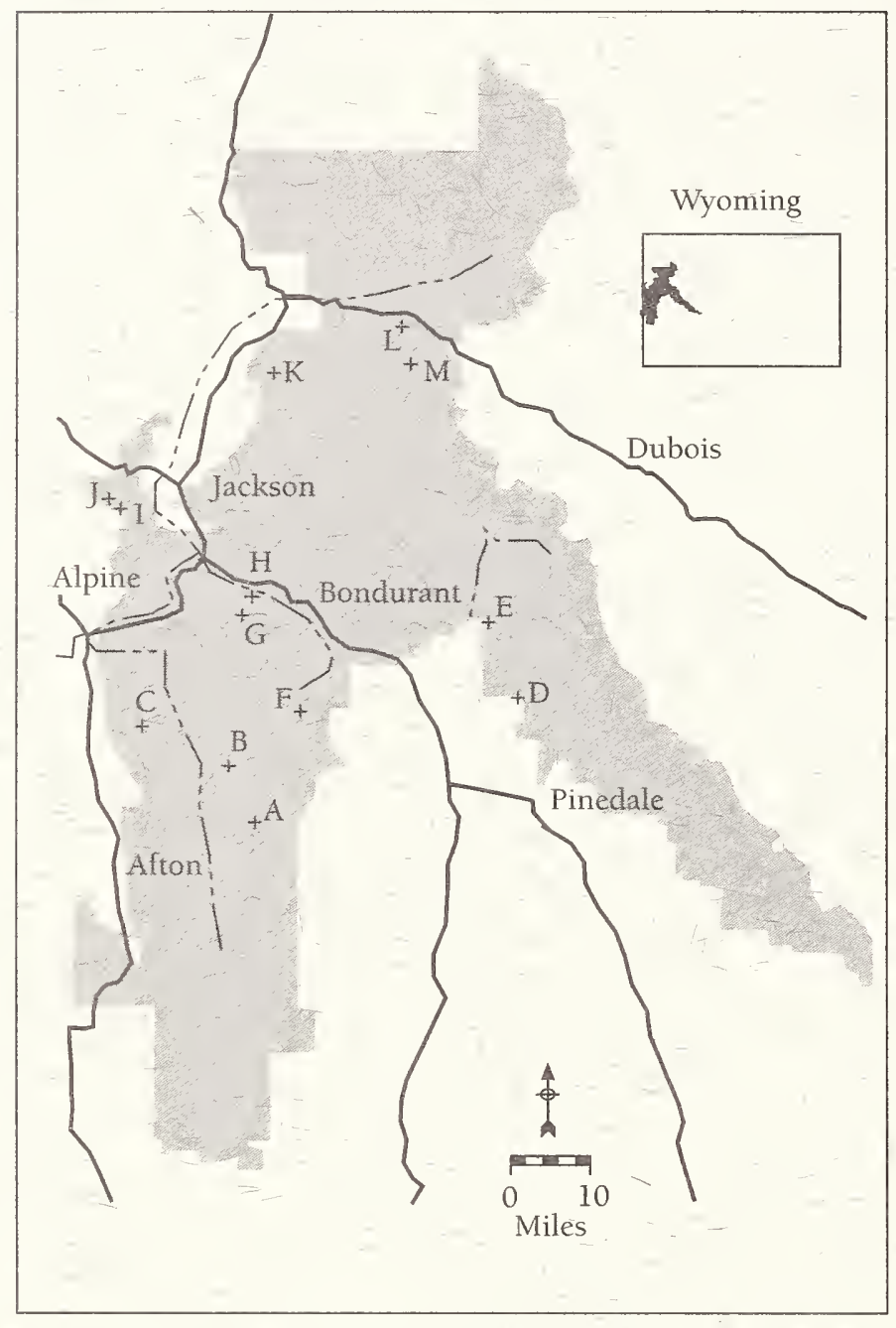

Figure 1. Summer 1995 field sites for CWD project, Bridger-Teton National Forest, Wyoming. Site codes are as follows: A- Sheep Creek; B- Blind Bull Creek; C- Murphy Creek; D- Willow Creek; E- S. Fork Gypsum Creek; F- Hoback River; G-Adams Creek; H- Buck Creek; I- Mosquito Creek; J- Moose Gulch. simulation in this paper. Climatically, the region is characterized by cold winters and abundant snowfall, while summers are warm with sporadic precipitation primarily from thunderstorms. Spring snowmelt floods are the primary mechanism influencing CWD transport in many small streams (Harmon et al. 1986), including those on the Bridger-Teton.

\section{Model Development}

Numerous riparian forest and stream CWD characteristics were sampled, including live tree attributes (species, height, d.b.h., lean in relation to the stream), riparian zone CWD properties (species, orientation relative to stream, end-of-log diameters, length), and stream CWD characteristics (species, end-of-log diameters, length, piece adjacency). Some of these data were then used to help parameterize the CWD model, which will be detailed in forthcoming work (Bragg et al. 1996). Once the CWD model predicted delivery of CWD to the stream, a simple formula is applied to determine periodic (10-year interval) stream CWD volume:

$$
\begin{aligned}
C W D \text { volume }= & \text { previous volume }+C W D \\
& \text { production }- \text { losses of CWD }
\end{aligned}
$$

Most research on the mechanics of CWD transport has been confined to steep, unstable streams in the Pacific Northwest affected by debris torrents (see Swanson et al. 1976, Swanson and Lienkaemper 1978, Bisson et al. 1987) and may not reflect the dominant processes influencing debris dynamics in the central Rockies (Young 1994, Richmond and Fausch 1995). In the absence of catastrophic

TABLE 1. Properties for selected Brider-Teton National Forest (WY) streams used in this study. All values are for

\begin{tabular}{|c|c|c|c|c|c|c|}
\hline Stream & Order & $\begin{array}{l}\text { Drainage } \\
\text { basin size } \\
\text { (ha) }\end{array}$ & $\begin{array}{l}\text { Mean } \\
\text { bankfull } \\
\text { width } \\
\text { (m) }\end{array}$ & $\begin{array}{c}\text { Reach } \\
\text { sinuosity }\end{array}$ & $\begin{array}{c}\text { Reach } \\
\text { gradient } \\
(\%)\end{array}$ & $\begin{array}{c}\text { Riparian } \\
\text { forest } \\
\text { density } \\
\left(\mathrm{m}^{2} / \mathrm{ha}\right)\end{array}$ \\
\hline Moose Gulch Creek & 1 & 414 & 3.4 & 1.12 & 2.0 & 23 \\
\hline Dry Lake Creek & 2 & 1033 & 5.5 & 1.05 & 3.5 & 33 \\
\hline Hoback River & 3 & 9965 & 14.5 & 1.02 & 1.5 & 31 \\
\hline
\end{tabular}
$250 \mathrm{~m}$ reaches sampled during the summer of 1995. 
TABLE 2. CWD parameters used with the model for this study. For an undisturbed old-growth stand (this example), we assume average cyclic ${ }^{1}$ CWD delivery equals average cyclic CWD loss (steady-state conditions).

\begin{tabular}{lccccc}
\hline Stream & $\begin{array}{c}\text { Mean bankfull } \\
\text { width } \\
(\mathrm{m})\end{array}$ & $\begin{array}{c}\text { Stream } \\
\text { CWD } \\
\text { volume } \\
\left(\mathrm{m}^{3} / 100 \mathrm{~m}\right)\end{array}$ & $\begin{array}{c}\text { Average } \\
\text { cyclic CWD } \\
\text { delivery } \\
\left(\mathrm{m}^{3} / 100 \mathrm{~m}\right)\end{array}$ & $\begin{array}{c}\text { Cyclic } \\
\text { CWD turnover } \\
\text { rate }^{2}\end{array}$ & $\begin{array}{c}\text { Average cyclic } \\
\text { CWD loss } \\
\left(\mathrm{m}^{3} / 100 \mathrm{~m}\right)\end{array}$ \\
\hline Moose Gulch Creek & 3.4 & 21.0 & 2.7 & 0.13 & 2.7 \\
Dry Lake Creek & 5.5 & 8.6 & 2.3 & 0.26 & 2.3 \\
Hoback River & 14.5 & 11.9 & 3.2 & 0.27 & 3.2 \\
\hline
\end{tabular}

${ }^{1}$ 'Cyclic' refers to the use of a 10 -year time step to reflect synchronisity with $\mathrm{FV} S$ vegetation predictions.

${ }^{2}$ Cyclic CWD turnover rate is the ration of average cyclic CWD loss to stream CWD volume at $t=0$.

disturbance, several authors have hypothesized stable long-term CWD loads (Froehlich 1973, Swanson and Lienkaemper 1978, Likens and Bilby 1982). We also assumed that the CWD volumes existed at a steady-state condition in which the long-term loss of CWD (transport off-site + decay) is approximately equivalent to inputs from adjacent forests and deposition of materials from upstream. Table 2 lists the CWD characteristics applied to simulated streams.

Generally, losses of stream CWD arise from decomposition and transport (Swanson et al. 1982, Ruediger and Ward 1996). With the exception of flood events, small streams are considered capable of transporting only small pieces of CWD (Harmon et al. 1986, Bisson et al. 1987), and within-stream decomposition is negligible compared to annual inputs (Bisson et al. 1987). Small streams, because of their smaller dimensions and lower flow rates, are able to retain higher CWD loads than larger streams (Swanson et al. 1982, Lienkaemper and Swanson 1987, Ruediger and Ward 1996), which are capable of moving whole trees (especially during peak flows).

The Forest Vegetation Simulator [FVS, also known as Prognosis (Stage 1973, Wykoff et al. 1982)] is a growth-and-yield model with the capacity to simulate both forest growth patterns and the influence of management. This model uses data taken from the stand of interest and projects the change in physical characteristics (e.g., height, diameters, stocking, density) through time. FVS can be customized to produce realistic forest dynamics, including regeneration, growth rate, and mortality patterns for many different locations. For this exercise, we have utilized the Teton Variant (version 6.2) of FVS.

Since FVS is capable of simulating multiple harvests over long periods of time (up to 400 years), it is possible to evaluate the long-term consequences of both past and present management, and estimate CWD recovery periods for streams influenced by timber harvests and/or CWD removals. Six different treatments were tested on a first, second, and third order stream (Table 3).

In low intensity stream treatments (i.e., no debris removal), we assume that the streams move a constant ratio of CWD during each cycle (equal to the amount on average delivered every cycle in undisturbed stands), regardless of CWD volume actually delivered after treatment. The CWD attrition rates reported in Table 2 are similar to

TABLE 3. Permutations of riparian forest harvests and stream CWD cleaning treatments used in this paper (each was applied to all three stands).

No harvest, no stream cleaning (TMT\#1)

No harvest, stream cleaning $(\mathrm{TMT} \# 2)$
Clearcut, no stream cleaning (TMT\#3)

Clearcut, stream cleaning (TMT\#4)
Selective harvest, no stream cleaning (TMT\#5)

Selective harvest, stream cleaning (TMT\#6) 
those used by others (e.g., Murphy and Koski 1989). For high intensity treatments (i.e., debris cleaning), we eliminate all CWD in the stream at the first treatment, but not during subsequent harvests (simulating current conditions, in which streams were cleared in the past but not with present or future harvests). We also assume a neutral-impact harvest system in those stands being treated (i.e., no slash was deposited in the stream). This final assumption, while convenient for modeling purposes, may not hold in some harvested areas especially after clearcutting (Froehlich 1973, Potts and Anderson 1990).

Thirty replicates of the CWD model were generated on each treatment to calculate average CWD delivery over a simulation period of 300 years. Three subject stands were modeled as $15 \mathrm{~m}$ strips of forest immediately adjacent to the stream (Bragg et al. 1996). CWD delivery results are reported as cubic meters per $100 \mathrm{~m}$ of stream reach. After allowing FVS a period of adjustment to incorporate both regeneration and mortality, all harvest treatments experienced an initial harvest at year 50, and then a target stockingl of $195 \mathrm{m3} /$ ha was established as the threshold for harvest scheduling by FVS. We used CWD delivery to the stream, net change in stream CWD volume, and differences in merchantable harvest volumes to evaluate the ecological and silvicultural effects of each treatment.

\section{Results and Discussion}

Changes in stream CWD loads through time can be found in Figures 2 - 4. The initial drop in CWD delivery before the first harvest (years 0 - 49) was an artifact of stand dynamics produced by FVS reflecting the flux between recruitment of new mature trees and mortality settings. The no harvest, no stream clearing treatment (TMT\#1) vacillates somewhat over the length of the simulation period but generally follows the original steady-state stream CWD volumes. While there is little long-term data on stream CWD

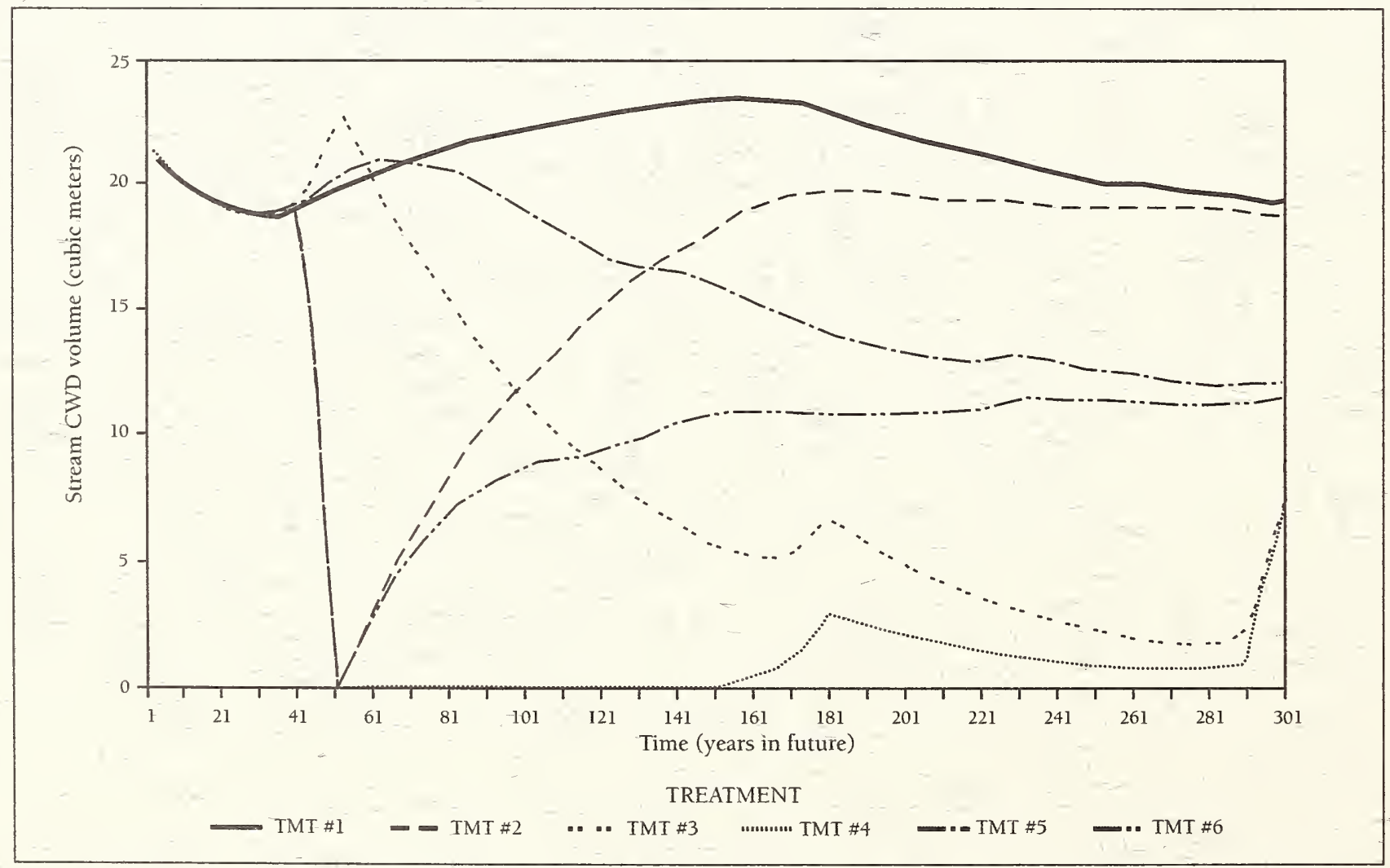

FIGURE 2. Stream CWD loads (per $100 \mathrm{~m}$ reach) through the simulation period, Moose Gulch Creek, Wyoming.

${ }^{1}$ The target stocking of $195 \mathrm{~m}^{3} / \mathrm{ha}$ was used because it produced FV S-simulated rotation ages of $110-140$ years, which follow silvicultural recommendations of Long (1994). 


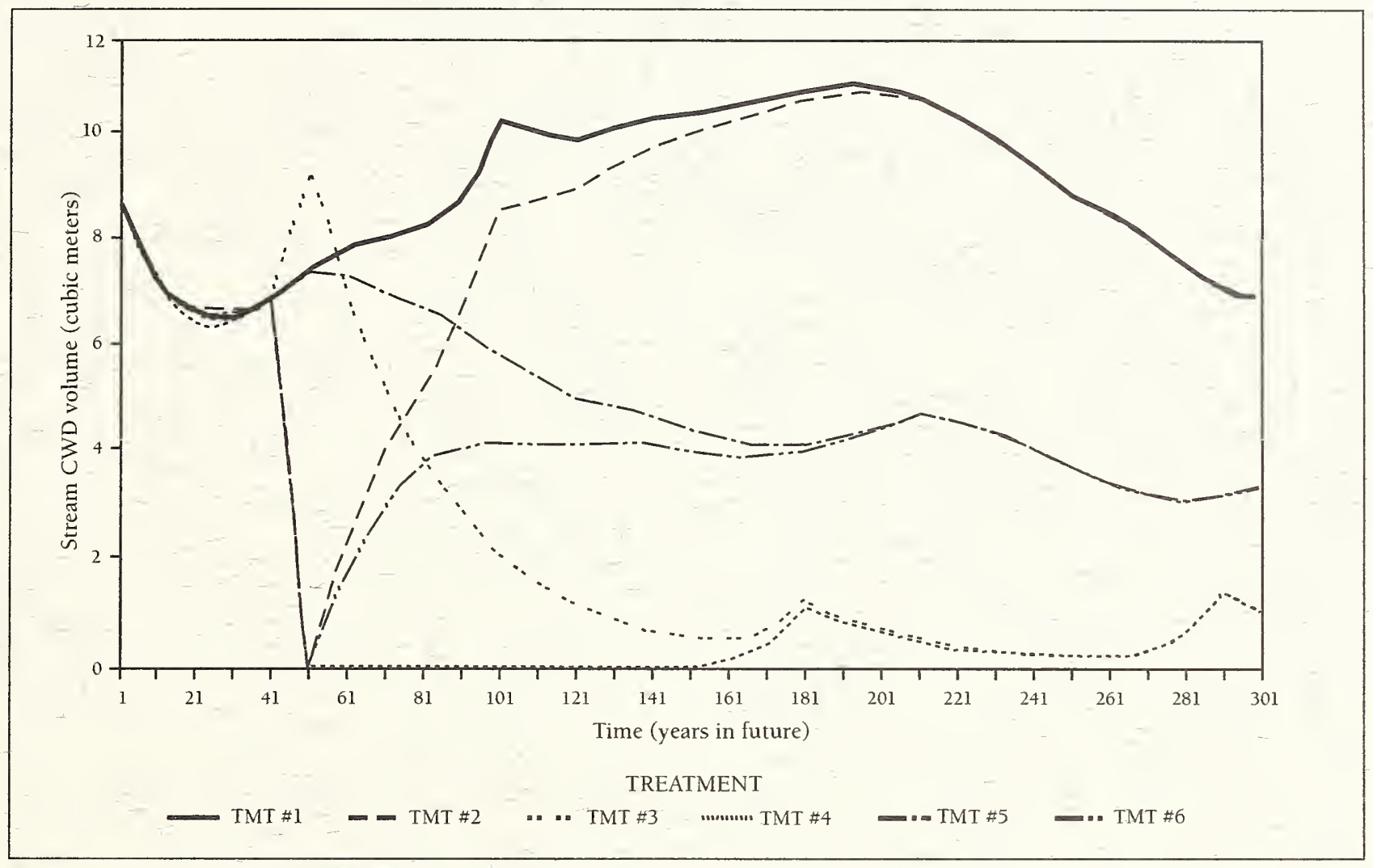

FIGURE 3. Stream CWD loads (per $100 \mathrm{~m}$ reach) through the simulation period, Dry Lake Creek, Wyoming

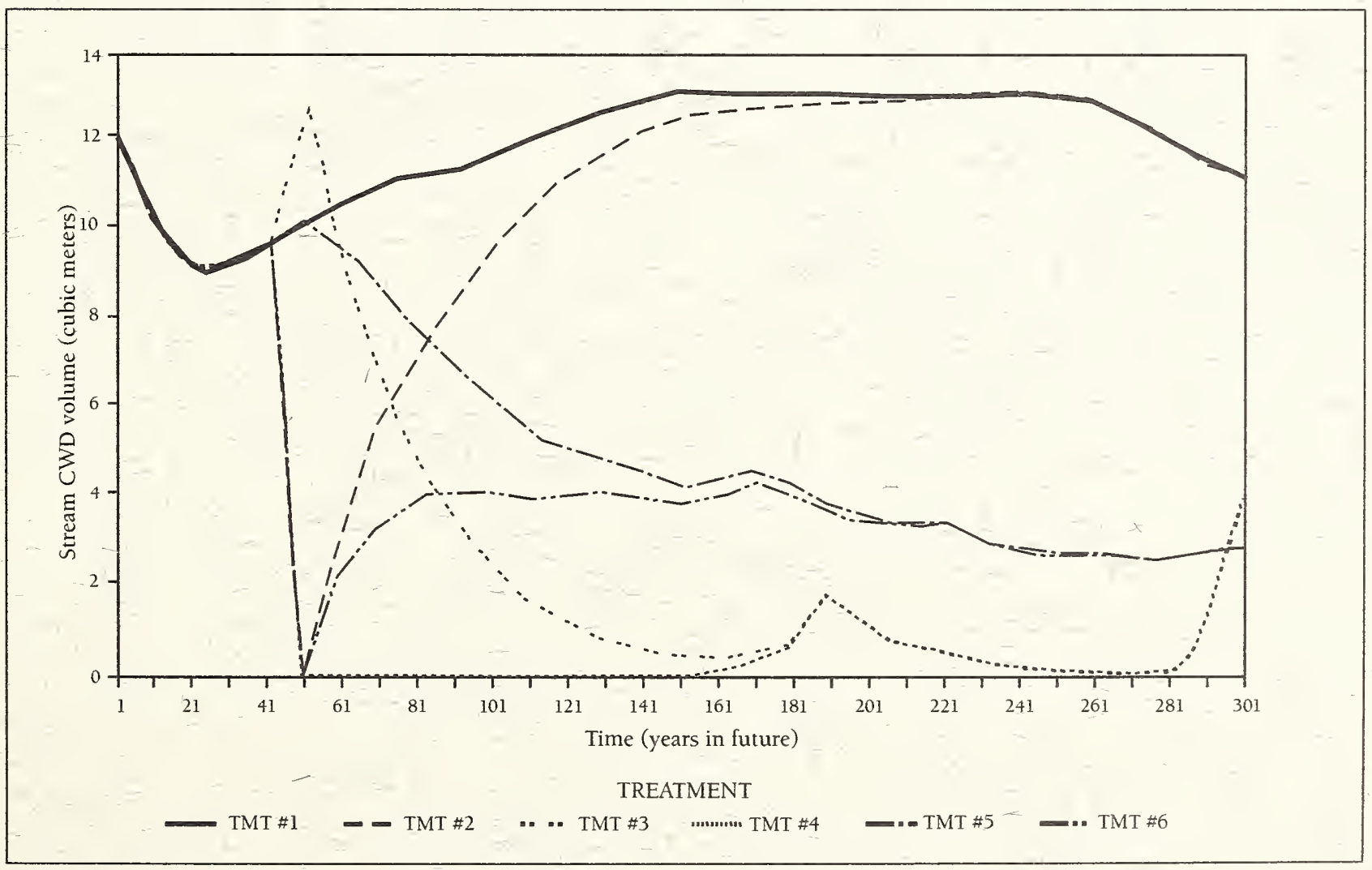

FIGURE 4. Stream CWD loads (per $100 \mathrm{~m}$ reach) through the simulation period, Hoback River, Wyoming 
retention, this trend seems to pattern natural riparian forest fluctuations in stand density (Froehlich 1973, Likens and Bilby 1982). As expected, stream CWD loads changed drastically with stream cleaning, even under a no-harvest system. Complete stream CWD removal under unmodified canopies (TMT\#2) resulted in decades-long lags in CWD volume for all simulations (Figures 2 - 4). These streams were predicted to eventually re-establish uncleared stream CWD loads. Depending on the steady-state CWD loads, the productivity of the stand, and cyclic CWD turnover rates (Table 2), the lag in CWD stocking for undisturbed riparian forests ranged from approximately 80 years at Dry Lake Creek and the Hoback River to 110 years for Moose Gulch Creek. While these lags are less than what Murphy and Koski (1989) predicted for some Alaskan streams, the overall CWD trends are quite similar, with most of the differences likely resulting from different methodologies, model assumptions; and species growth rates.

However, while the gross volumes may be similar, it is difficult to say if these two conditions should be considered functionally equivalent. The dimensions of the CWD stored by the treatments (TMT\#1 versus TMT\#2) is probably very different, as cleared streams tend to lack the largest pieces of wood. Even 250 years after cleaning, it is unlikely that a similar volume of very large trunks and rootwads could be replaced, as these structures are slow to accumulate and may persist for centuries in undisturbed systems (Swanson et al. 1976, Bisson et al. 1987, Murphy and Koski 1989).

As suggested by the model results, applying standard harvesting systems in riparian forests, even without repeated stream clearings, can significantly depress total CWD volume within a stream (also see Murphy and Koski 1989). Rainville et al. (1985) found similar responses in their simulation of harvest treatments of northern Idaho forests. Selective harvesting (here simulated by periodic thinnings of the largest size classes when the stand volume exceeded $195 \mathrm{~m} 3 / \mathrm{ha}$ ) instituted a gradual but significant decline in stream CWD volume as both mortality rates and the number of large trees declined. Increased tree vigor, generally thought to be a favorable aspect of managed forests, did serve to limit the potential amount of CWD entering the stream because weakened trees were the most likely candidates to succumb under our assumptions. The removal of most of the largest size classes (common practice with selection systems) also decreased the volume of CWD delivered by removing the biggest pieces (which represent a large share of total CWD). Although not addressed by the CWD model, this change may further affect CWD storage as large pieces help to store smaller, more transient pieces of CWD (Bisson et al. 1987). Selection systems resulted in higher post-harvest CWD levels than clearcutting because there were residual trees > $10 \mathrm{~cm}$ d.b.h., whereas clearcutting removed all merchantable (high CWD potential) stems. Both treatments that did not involve stream clearings (TMT\#3 and TMT\#5) led to significant depletion of total CWD storage in the streams, but were still able to retain some CWD, probably as large, preharvest logs and rootwads [see Andrus et al. (1988) and Ralph et al. (1994)]. Both clearcut and selective harvests combined with stream cleaning (TMT\#4 and TMT\#6) resulted in longterm loss of CWD and forests less able to replenish depleted stream CWD loads. Stream cleaning coupled with repeated clearcutting largely eliminated all CWD from the streams for almost a century after treatment and only permitted minimal restocking. Under these conditions, the CWD model indicates that even $10 \%$ of pre-logging CWD volumes will be difficult to maintain (Figures 2 - 4).

Selective harvest systems are capable of delivering some CWD consistently from the riparian forest. Table 4 presents the differences in both timber and CWD production under the management systems applied during this simulation. As this table shows, both harvest systems reduce cumulative CWD production significantly from no harvest. However, according to FV S growth and yield projections on the subject stands, a selection system can produce anywhere from 68 $104 \%$ of the harvest volume of a clearcut over a 300 year period while retaining $38-65 \%$ of no harvest CWD volumes. Selection systems appear to offer a compromise solution by preserving some harvest while recruiting and retaining a substantial portion of stream CWD. 
TABLE 4. Predicted harvest volume versus cumulative (300 year) CWD production for simulated treatments.

\begin{tabular}{|c|c|c|c|c|c|c|}
\hline Stream & $\begin{array}{l}\text { Harvest } \\
\text { treatment }\end{array}$ & $\begin{array}{c}\text { Number of } \\
\text { harvests }\end{array}$ & $\begin{array}{l}\text { CWD volume } \\
\text { delivered } \\
(\mathrm{m} 3 / 100 \mathrm{~m})\end{array}$ & $\begin{array}{l}\text { Percent of no } \\
\text { harvest }\end{array}$ & $\begin{array}{c}\text { Merchantable } \\
\text { harvest volume } \\
\text { (m3/ha) }\end{array}$ & $\begin{array}{l}\text { Percent of } \\
\text { clearcut }\end{array}$ \\
\hline \multirow{3}{*}{ Moose Gulch Creek } & clearcut & 3 & 24.4 & 29 & 264 & -- \\
\hline & selection & 4 & 54.8 & 65 & 180 & 68 \\
\hline & none & $-n / a$ & 84.4 & -- & 0 & 0 \\
\hline \multirow[t]{3}{*}{ Dry Lake Creek } & clearcut & 3 & 12.5 & 18 & 254 & -- \\
\hline & selection & 5 & 34.8 & 51 & 215 & 85 \\
\hline & none & $\mathrm{n} / \mathrm{a}$ & 96.6 & -- & 0 & 0 \\
\hline \multirow[t]{3}{*}{ Hoback River } & clearcut & 3 & 20.5 & 21 & 373 & -- \\
\hline & selection & 8 & 37.1 & 38 & 389 & 104 \\
\hline & none & $\mathrm{n} / \mathrm{a}$ & 96.6 & -- & 0 & 0 \\
\hline
\end{tabular}

\section{Conclusions}

While the CWD model involves many assumptions and oversimplifies the processes involved in CWD formation and delivery, it is suggestive of the trends that are likely to occur with or without timber management. Consideration of the CWD dynamics involved in these situations can be used to accommodate both forest and CWD production, as well as ameliorate past management practices. Critical to such endeavors, however, is recognition that each ecosystem [and even portions of ecosystems (see Richmond and Fausch 1995)] will respond differently to treatment, depending on riparian forest properties, site productivity, the size and nature of the stream of interest, and the effectiveness of management.

Many of the most productive spruce-fir forests in the central Rocky Mountains are in immediate proximity to streams, which also frequently provide critical habitat for riparian-dependent species. There is an increasing need to examine riparian systems to determine whether trees can be harvested without degrading ripariandependent values. Clearcutting is generally unable to support CWD delivery to riparian systems, as it keeps most of the adjacent forest in early successional stages for long periods of time, thereby failing to replenish streams with large, stable CWD. Selective cuts under some situations, however, may be tolerable in that this harvest system retains continuous mature forest cover along the riparian zone and can potentially sustain some level of CWD delivery.

A pro-active approach towards integrated riparian system management may also prove beneficial. Reserving declining trees or girdling larger, healthy trees in the immediate proximity of stream banks, especially those whose lean favors entrance into the stream, should serve to supply large CWD during periods of stand regrowth. While not represented in this study, the incorporation of FVS should eventually permit users to also simulate stochastic or cyclic natural catastrophic disturbance (e.g., fire) through mortality adjustments, thereby better mimicking natural riparian pattern and process.

Of course, each riparian system should be evaluated on a case-by-case basis, but active forest management and preservation of many streams qualities are not necessarily mutually exclusive events. This is one of several models designed to predict CWD dynamics through integration with growth and yield models (Cimon 1983, Rainville et al. 1985, Van Sickle and Gregory 1990), and shows promise for evaluating harvest treatment 
The United States Department of Agriculture (USDA) Forest Service is a diverse organization committed to equal opportunity in employment and program delivery. USDA prohibits discrimination on the basis of race, color, national origin, sex, religion, age, disability, political affiliation and familial status. Persons believing they have been discriminated against should contact the Secretary, U.S. Department of Agriculture, Washington, DC 20250, or call (202) 720-7327 (voice) or (202) 720-1127 (TDD).

The use of trade, firm or corporation names in this publication is for the information and convenience of the reader. Such use does not constitute an official endorsement or approval by the U.S. Department of Agriculture or any product or service to the exclusion of others that may be suitable. 